\title{
The impact of accommodation entrepreneurship activities on Islamic tourism (Umrah) development: An empirical evidence from Saudi Arabia
}

\author{
Mohammed Ayoub Ledhem \\ LEPPESE laboratory, Department of Economics, University Centre of Maghnia, Maghnia, Algeria \\ ledhem.edu@gmail.com \\ Warda Moussaoui \\ Department of Economics, Dr Yahia Fares University of Medea, Medea, Algeria \\ moussaoui.warda@univ-medea.dz
}

Received: 29/10/2020 Revised: 14/11/2020 Accepted: 1/12/2020 DOI: https://doi.org/10.31559/IJHTS2020.1.2.4

\begin{abstract}
:
Currently, academics have given an intense interest in investigating the factors that promote the tourism industry as evidenced by the growing studies which investigate the impact of accommodation services as one of the main factors in the tourism industry. However, this investigated impact is missing in the Islamic tourism industry. For this reason, this paper is filling this gap by investigating the impact of accommodation entrepreneurship activities on Islamic tourism (Umrah pilgrimage) in Saudi Arabia. This paper applied a robust non-parametric approach of bootstrapped quantile regression to estimate the effect of accommodation entrepreneurship activities on Islamic tourism (Umrah pilgrimage) using a sample of the total Umrah pilgrims (Islamic tourists) as a proxy for Islamic tourism (Umrah pilgrimage) development and total accommodation entrepreneurship activities as an independent variable covering a period from 2010 until 2018. The findings demonstrated that accommodation entrepreneurship activities are promoting Islamic tourism (Umrah pilgrimage) industry in Saudi Arabia. The findings also indicated that accommodation entrepreneurship activities are one of the main factors that promote Islamic tourism (Umrah) in Saudi Arabia alongside Islamic life and belief, and religious loyalty.
\end{abstract}

Keywords: Islamic tourism; Halal tourism; Umrah pilgrimage; Accommodation entrepreneurship activities; Bootstrapped quantile regression.

\section{Introduction}

Lately, academics have shown a great interest in analyzing the importance of religion in the tourism industry, and the connection between the Islamic and the tourism sector is growing in interest and attractiveness, as evidenced by the increasing academic work published under the term of Halal or Islamic tourism (ALSINI, EKIZ, and HUSSAIN, 2019). Following this path of academic research in the Islamic tourism field, this paper aims to investigate the impact of accommodation entrepreneurship activities on Islamic tourism (Umrah) development in Saudi Arabia.

Islamic tourism is a concept that arose in recent years due to the growth of Muslims around the world (Jamal, Raj, and Griffin, 2019). The Muslim population is increasing more quickly than any other religion. Approximately $25 \%$ of the global population has been identified by the Pew Research Center (2011). The worldwide Muslim population is expected to rise by 2030 from 1.6 billion in 2010 to 2.2 billion. The Muslim population will grow to an approximate 2.76 billion by 2050 , or $29.7 \%$ of the world's population if this pattern continues. Table 1 indicates the rise in Muslim population by area from 2010 to 2030. These statistics show Islam to be one of the world's largest and fastest-growing sects, with a huge effect on the halal industry. 


\begin{tabular}{|c|c|c|c|c|}
\hline & \multicolumn{2}{|c|}{2010} & \multicolumn{2}{|c|}{2030} \\
\hline & $\begin{array}{l}\text { Estimated Muslim } \\
\text { population ('000) }\end{array}$ & $\begin{array}{l}\text { Estimated \% of the global } \\
\text { Muslim population }\end{array}$ & $\begin{array}{l}\text { Estimated Muslim } \\
\text { population ('000) }\end{array}$ & $\begin{array}{l}\text { Estimated \% of the global } \\
\text { Muslim population }\end{array}$ \\
\hline World & $1,619,314$ & $100 \%$ & $2,190,154$ & $100 \%$ \\
\hline Asia-Pacific & $1,005,507$ & $62.1 \%$ & $1,295,625$ & $59.2 \%$ \\
\hline Middle East-North Africa & 321,869 & $19.9 \%$ & 439,453 & $20.1 \%$ \\
\hline Sub-Saharan Africa & 242,544 & $15.0 \%$ & 385,936 & $17.6 \%$ \\
\hline Europe & 44,138 & $2.7 \%$ & 58,209 & $2.7 \%$ \\
\hline Americas & 5,256 & $0.3 \%$ & 10,927 & $0.5 \%$ \\
\hline
\end{tabular}

Source: Hall and Prayag, 2020.

Islamic tourism or Halal tourism has shown a remarkable situation in the tourism sector and has the opportunity to enhance further. From a broader point of view, the Crescent Ranking in 2016 also found that an unprecedented 117 million foreign Muslim tourists are worldwide, rising to 168 million visitors by 2020, accounting for $11 \%$ of the world economy, with a market valuation over 200 billion dollars (Hall and Prayag, 2020). Islamic tourism is built on the fact that the business must fulfil the criteria of the Quran and the Hadith, Muslim travellers must carry out their religious obligations, including five-times-day prayer and halal-food for a decent Muslim (Hall and Prayag, 2020).

The largest form of widespread religious tourism in the world is the Islamic tourism which takes place in Makkah, Saudi Arabia, during the annual Hajj pilgrimage (Jamal, Raj, and Griffin, 2019). Due to the most popular and sacred places in Makkah (Holy Kaaba, Al-Masjid Al-Haram) and Madinah (Prophet's Mosque, Al-Masjid AnNabawi) for Muslims, tourism in Saudi Arabia has its special significance (Ekiz, Öter, and Stephenson, 2017). Lately, Islamic tourism revenues (Hajj and Umrah) are promoting economic growth and development in Saudi Arabia alongside the oil revenues (Bokhari, 2018), which make the Islamic tourism plays a progressively vital role in economic growth and development.

For religious reasons, Muslims around the world typically tend to visit Makkah and Medina at least once in their lives for pilgrimage: Umrah and/or Hajj (Jamal, Raj, and Griffin, 2019). Both are ways of pilgrimage that are performed by Muslims as a display of their religion. An Umrah is viewed as a minor or minor pilgrimage by Muslims, while a Hajj is a large pilgrimage. From a religious standpoint, relative to conducting an Umrah, the Hajj holds greater weight and value (Jamal, Raj, and Griffin, 2019). The Umrah is a pilgrimage that can be carried out at any time of the year or in conjunction with a Hajj, while, according to the Islamic calendar, Hajj can only be performed at a certain time of the year (Bavik, Ekiz, and Xu, 2014).

Lately, many studies focused on the role of accommodation services on the attracting of tourists (Ekong and Imikan, 2016; Karthick and Ganesh, 2018; Song, Xie, Park, and Chen, 2020). Therefore, due to growing numbers of Umrah pilgrims to Saudi Arabia (Figure. 1), a question arises if the accommodation services in Saudi Arabia has a major role in bringing Umrah pilgrims alongside the Islamic religion loyalty motives. What necessitates the obligation to answer this question is the growth of accommodation entrepreneurship activities in Saudi Arabia alongside the growing number of Umrah pilgrims in Figure 1.

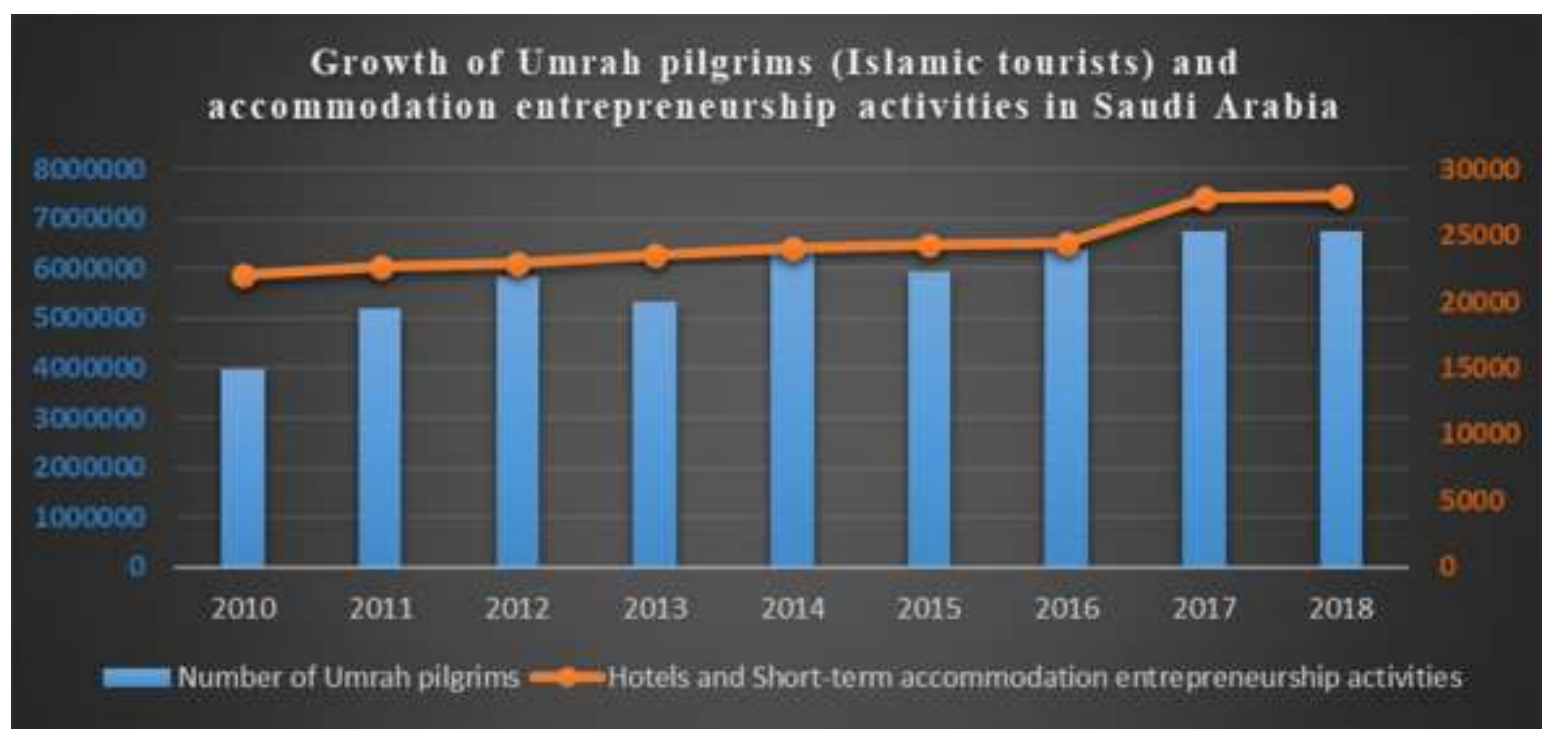

Figure (1): Growth of Umrah pilgrims (Islamic tourists) and Accommodation entrepreneurship activities in Saudi Arabia (2010-2018)

Sources: Prepared by authors based on the statistics of the Ministry of Hajj and Umrah, and General Authority for Statistics of Saudi Arabia. 
Accommodation services play a major role in attracting tourists worldwide (Chin, Law, Lo, and Ramayah, 2018; Karthick and Ganesh, 2018; Jeaheng, Al-Ansi, and Han, 2019; Akhy and Roy, 2020; Hassanli and Ashwell, 2020). Therefore, because of the growing number of accommodation entrepreneurship activities and Umrah pilgrims (Islamic tourist) in Saudi Arabia, it is necessary to examine the effect of accommodation entrepreneurship activities on Umrah pilgrimage development. Thus, this study is answering this question: "Does Accommodation entrepreneurship activities promote the Islamic tourism industry (Umrah pilgrimage) in Saudi Arabia?"

\section{Literature review}

Islamic tourism or 'Halal tourism' is a relatively new and under-researched theme is that a limited amount of scientific and academic productions was supplied by the Web of Science when the term was searched in this scientific database (VARGAS-SÁNCHEZ and MORAL-MORAL, 2018). According to VARGAS-SÁNCHEZ and MORALMORAL (2018), before 2017, only 13 (one of them was an editorial) articles of Islamic tourism (Halal tourism) have been published in the last three years (2014-2016), and 10 of these were in 2016. Therefore, this paper is expanding literature on the topic of Islamic tourism by investigating the impact of accommodation entrepreneurship activities on Islamic tourism (Umrah) development. According to Ekong and Imikan (2016), Karthick and Ganesh (2018), and Song et al. (2020), accommodation becomes one of the main factors that affect the tourism industry. For this reason, many studies had been appeared investigating the impact of accommodation services on attracting tourists. Yet, to the best of the author's knowledge, this investigated impact is missing in the Islamic tourism industry which produces a literature gap. Thus, this paper aims to fill this literature gap by investigating the impact of accommodation entrepreneurship activities on Islamic tourism (Umrah pilgrimage) development based on the synchronized behaviour of the growing number of accommodation entrepreneurship activities and Umrah pilgrims (Islamic tourist) in Saudi Arabia (Figure 1). Therefore, it is believed that this paper will make a significant contribution to literature.

According to Jamal et al. (2019), Islamic tourism in Saudi Arabia is determined by Umrah and Hajj. So, in the context of Umrah and Hajj, this study is focusing on Umrah. Umrah phenomena have been discussed from many different disciplinary perspectives, including sociology (Sahin, Aker, and Tuncel, 2015; Wu and Mursid, 2019), business (Bokhari, 2018; Othman, Harun, and Nazeer, 2018; Wu and Mursid, 2019), health (Charrel, Nougairede, Brouqui, Raoult, and Gautret, 2015; Ebrahim and Memish, 2020) and psychology (Jamal, Raj, and Griffin, 2019; Hall and Prayag, 2020). However, this paper is focusing on the effect of accommodation entrepreneurship business on the attraction of Umrah pilgrims to Saudi Arabia. Thus, this paper is reviewing some notable studies of Umrah in business and psychology perspectives. In a study by Wu and Mursid (2019), they investigated the effect of Umrah pilgrim' participation on loyalty and how Umrah pilgrims' participation is motivated by organizational rewards. They applied the purposive sampling method with structural equation modelling on a sample of 439 Umrah pilgrims. They found that the organizational rewards affected Umrah pilgrims' participation, and Umrah pilgrims' participation was affecting directly Umrah pilgrims' loyalty.

In the same area of Umrah pilgrimage, Almuhrzi and Alsawafi (2017) discussed the towards understanding motivations for Umrah pilgrimage in Oman. They used a quantitative survey-based approach to investigate Umrah pilgrimage motives beyond the Hajj season. They found that, relative to religious devotion, religious commitment earned a lower score, meaning that although the Umrah pilgrims can show internal attachment to Islamic traditions.

Since this paper is investigating the effect of accommodation entrepreneurship activities on Islamic tourism (Umrah pilgrimage) development, it is necessary to review some notable studies on the relationship between entrepreneurship and tourism, and also, the relationship between accommodation and tourism.

In the context of entrepreneurship and tourism relationship, many studies demonstrated that entrepreneurship is stimulating tourism. Ohe (2020) explored the relationship between entrepreneurship and community-based rural tourism in Japan. Ohe (2020) used microeconomic approaches based on empirical models. Ohe (2020) demonstrated that entrepreneurship activities can promote rural tourism in Japan and tourism industry in Japan generally.

Similarly, Sheldon and Daniele (2017) explored the link between social entrepreneurship and tourism from many aspects of institutional and policy support for tourism social entrepreneurship based on the theory and practice studies. They found that social entrepreneurship is beneficial for tourism and creates many business opportunities in the tourism value chain.

In the same vein, both Lee-Ross and Lashley, (2008) and Page and Ateljevic (2009) determined that entrepreneurship through small and medium enterprises is stimulating tourism and creates many business potentials in the tourism and hospitality industry based on international perspectives.

Concerning accommodation and tourism relationship, Ekong and Imikan (2016) evaluated the effect of hotels on the socio-economic growth in Akwa Ibom State. They used the method of random sampling among 30 hotels through 300 questionnaires. Their findings showed that hotels accommodation affect employment, revenue 
generation and socio-economic development and attracts tourists and visitors and promote the tourism industry in Akwa Ibom State.

A similar study on the effect of accommodation on promoting tourism, Karthick and Ganesh (2018) have examined the role of accommodation in promoting local tourism in Tamilnadu, they applied statistical analysis on the hotel industry to analyze the effect of promotion on tourism. Their findings indicate that accommodation in Tamilnadu is promoting tourism.

In a recent study, Song et al. (2020) investigated the impact of the accommodation on tourist attractions in China. They applied two-way fixed effects to estimate the impact of the accommodation on attractions of tourists. Their findings indicate that accommodation sharing is attracting tourists increasingly with $15.4 \%$ in China.

Based on the literature review, this paper found that accommodation and entrepreneurship are promoting tourism industry by enhancing the tourist attractions. However, all previous studies didn't investigate the accommodation entrepreneurship in the Islamic tourism industry. Thus, this is a literature gap need to be filled. For this reason, this paper is investigating if accommodation entrepreneurship activities have a positive impact on promoting Islamic tourism (Umrah pilgrimage) in Saudi Arabia. Therefore, this paper is making a substantial contribution to the literature.

\section{Research Methodology}

\subsection{Data and sample}

This study employed data of Umrah pilgrims (Islamic tourists) to Saudi Arabia based on annual datasets from the Ministry of Hajj and Umrah in Saudi Arabia, and annual datasets of accommodation entrepreneurship activities extracted from the General Authority for Statistics in Saudi Arabia spanning from 2010 to 2018.

Accommodation entrepreneurship activities are the sum of hotels short term accommodation activities establishments, camping grounds and recreational vehicle parks and trailer parks establishments, and other accommodation of furnished residential units.

\subsection{Experimental variables}

This study used Number of Umrah pilgrims (Islamic tourists) to Saudi Arabia (UMRAH) as a dependent variable.

To investigate the impact of accommodation entrepreneurship activities on Umrah pilgrims (Islamic tourist), this study employed accommodation as an independent variable (ACCOMMODATION).

\subsection{Estimating model}

This research examined the link between Umrah pilgrimage (Islamic tourism) and accommodation entrepreneurship activities in the following model:

$$
\text { UMRAH }_{\text {it }}=\alpha_{0}+\alpha_{1} \text { ACCOMMODATION }_{\text {it }}+\xi_{\text {it }}
$$

Where $\alpha_{0}$ is a constant term, $\alpha_{1}$ is a coefficient, $\xi_{\text {it }}$ is an error term, UMRAH is a dependent variable, ACCOMMODATION is an independent variable.

\subsection{Econometric methodology}

Since this study has a small sample (2010-2018), it is better to use the robust statistical methods for the finite sample, According to Hahn (1995), Feng, He, and Hu (2011), and Nikitina, Paidi, and Furuoka (2019), when the sample in the empirical model that uses the quantile regression is small, it is better to use the bootstrapping as an effective technique of a robust resampling to get well-estimated results.

This study employed bootstrapped quantile regression to estimate and investigate whether accommodation entrepreneurship activities in Saudi Arabia attracts more Umrah pilgrims (Islamic tourists). Thus, this study applied quantile regression with bootstrap technique over 5 replications for a robust estimation which omits the heteroskedasticity and autocorrelation problem in regression (J. A. Machado and Silva, 2013; J. a. F. Machado, Parente, and Silva, 2019;).

A quantile regression methodology is a non-parametric approach, it was presented by Koenker and Bassett (1978). J. A. Machado and Silva (2013) and J. a. F. Machado et al., (2019) indicated that quantile regression was hired in many applied applications that provide a robust estimation free from the regression heteroskedasticity problem when the interest variables have diverse impacts on the dependent variable's restricted distribution (Mello and Perrelli, 2003).

Following Koenker and Bassett (1978), the restricted distribution' $\tau$ quantile of Yi given Xi is:

$$
Q_{\tau}\left(Y_{i} \mid X_{i}\right)=X_{i}^{\prime} \beta_{\tau}
$$

The constraint vector of the $\tau$ quantile among the conditional distribution is respected by:

$$
\hat{\beta}_{\tau}=\arg \min \sum_{i=1}^{N} \rho_{\tau}\left(Y_{i}-X_{i}^{\prime} \beta\right)
$$

Where the quantile loss function $\rho_{\tau}$ (.) is distinct as: 


$$
\begin{gathered}
\rho_{\tau}(u)=(\tau-1) u \text { for } u<0 \\
\rho_{\tau}(u)=\tau u \text { for } u \geq 0
\end{gathered}
$$

The equation (3) displays that the process of quantile regression permits for restraint heterogeneity with diverse values for $\tau$ in the interval $(0,1)$ which are the minimum weighted deviations sum, allowing us to get a whole representation of the pledge between an exogenous variable and endogenous variable (Jiang, Zhang, and Sun, 2019; J. a. F. Machado et al., 2019).

Furthermore, the quantile regression process is robust to outliers and exciting distributions because it can regulate the weight through the loss function. Unlike the OLS regression, the quantile regression does not limit to the standard error term (Jiang et al., 2019; J. a. F. Machado et al., 2019).

\section{Results and Discussion}

To choose the optimal quantiles for running regression, Figure 2 provides the graph of checking how accommodation entrepreneurship activities in Saudi Arabia is spreading over quantiles (q) using the GRQREG command of Azevedo (2011) which indicates the quantile regression coefficients graph. The lower quantiles (from $\mathrm{q}=0.05$ to $\mathrm{q}=0.2$ ) represent low accommodation entrepreneurship activities (ACCOMMODATION). Similarly, the intermediate quantiles (from $\mathrm{q}=0.2$ to $\mathrm{q}=0.5$ ) reflect normal accommodation entrepreneurship activities (ACCOMMODATION), while the upper quantiles $(q=0.7$ to $q=0.95$ ) indicate high accommodation entrepreneurship activities (ACCOMMODATION). Thus, this study performed the quantile regression at 0.2,0.5 and 0.7 quantile. Therefore, the estimating on 0.2 quantiles reflects low Umrah pilgrims (Islamic tourists), intermediate quantile of 0.5 which reflects intermediate Umrah pilgrims, and at the upper quantile of 0.7 reflects high Umrah pilgrims (Table 2).

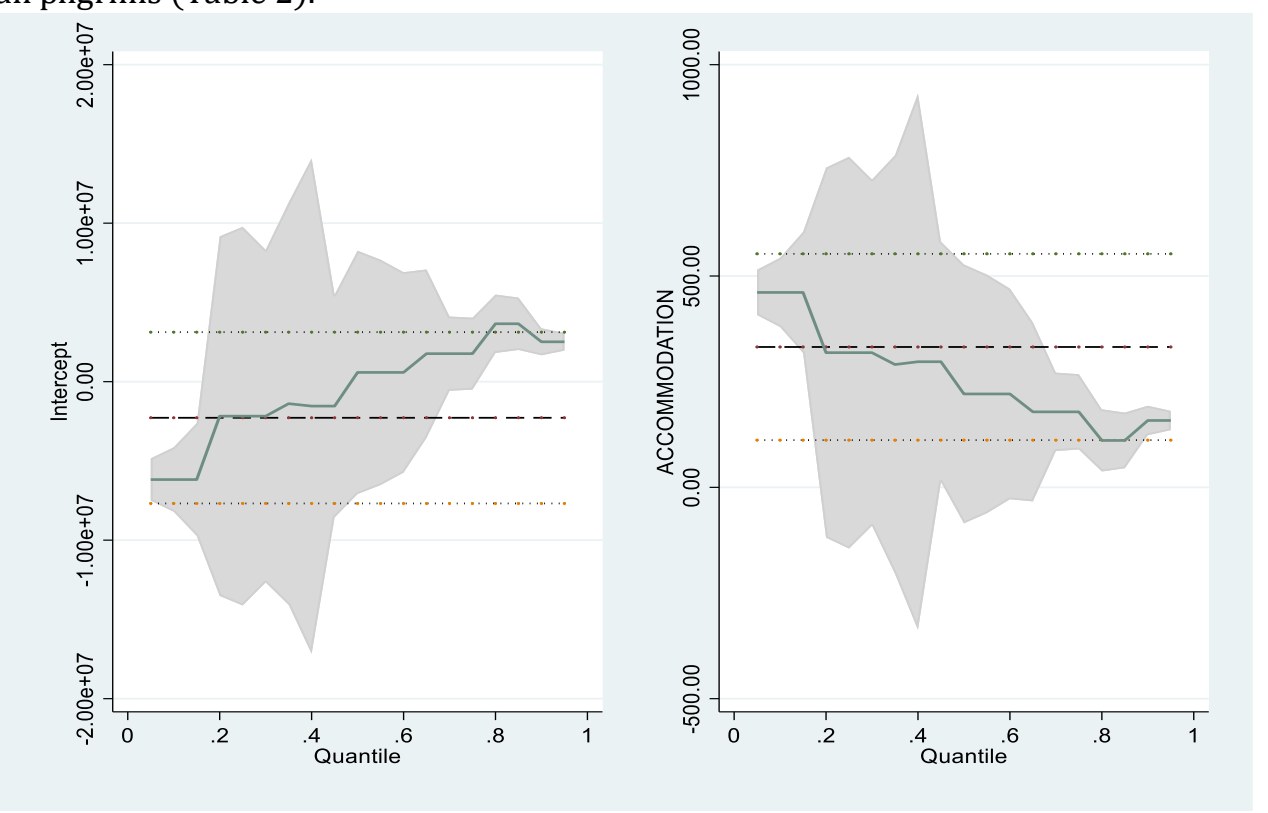

Figure (2): Graph of the variation in the coefficient over the conditional quantiles Sources: Prepared by authors

Using QPLOT command of Cox (2005), it is ideal to apply the symmetric quantile regression on 0.5 quantiles at intermediate quantiles of the number of Umrah pilgrims (UMRAH) as it is shown in Figure 3, which illustrated the number of Umrah pilgrims (UMRAH) reasonably symmetric at 0.5 quantiles. 


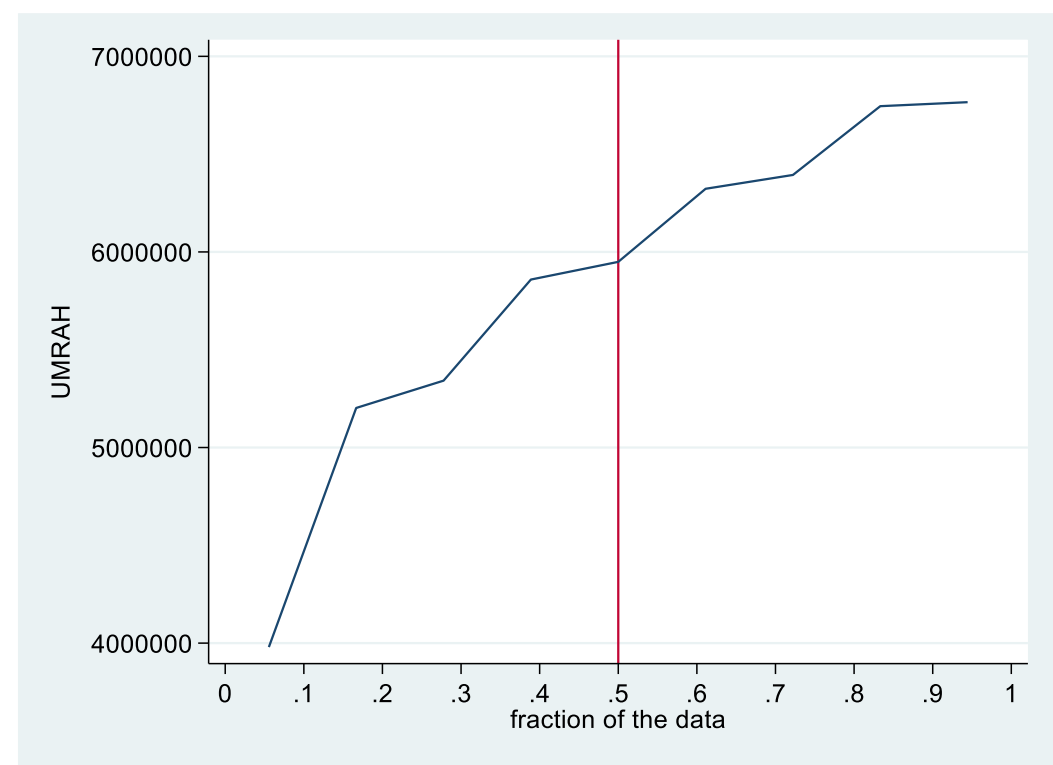

Figure (3): Graph of the symmetric UMRAH fraction data over quantiles Sources: Symmetric UMRAH fraction data over 0.5 quantiles

Table (2): Bootstrapped quantile regression with 5 replications at $0.2,0.5$ and 0.7 quantiles

\begin{tabular}{|c|c|c|c|c|c|c|}
\hline \multicolumn{7}{|c|}{$\begin{array}{l}\text { Simultaneous quantile regression } \\
\text { Bootstrap replications (5) } \\
\text { Number of obs }=9\end{array}$} \\
\hline UMRAH & Coef. & $\begin{array}{l}\text { Bootstrap } \\
\text { Std. Err. }\end{array}$ & $\mathrm{t}$ & $P>|t|$ & [95\% Conf. & Interval] \\
\hline \multicolumn{7}{|l|}{0.2 Quantile } \\
\hline ACCOMMODATION & 318.6303 & 162.0283 & 1.97 & $0.090^{*}$ & -64.50573 & 701.7663 \\
\hline Constant & -2175470 & 4327953 & -0.50 & 0.631 & $-1.24 \mathrm{e}+07$ & 8058512 \\
\hline \multicolumn{7}{|l|}{0.5 Quantile } \\
\hline ACCOMMODATION & 221.0311 & 57.74185 & 3.83 & $0.006^{* *}$ & 84.49333 & 357.5689 \\
\hline Constant & 585008.2 & 1623334 & 0.36 & 0.729 & -3253567 & 4423584 \\
\hline \multicolumn{7}{|l|}{0.7 Quantile } \\
\hline ACCOMMODATION & 178.6067 & 52.12746 & 3.43 & $0.011^{*}$ & 55.34482 & 301.8686 \\
\hline Constant & 1767377 & 1450639 & 1.22 & 0.263 & -1662839 & 5197593 \\
\hline
\end{tabular}

Sources: Bootstrap Quantile regression outputs prepared by authors

Note: * significant at the 0.05 level, ${ }^{* *}$ significant at the 0.01 level

Based on Table 2, the bootstrapped quantile regression at 0.7 quantiles indicated that accommodation entrepreneurship activities (ACCOMMODATION) are explaining the positive effect on Umrah pilgrims in Saudi Arabia on a significance level of $1 \%$ ( $p$-value of ACCOMMODATION $=0.011$ which is strongly less than 0.01 ). Whereas 0.5 quantile indicates on a significance level of $5 \%$ that accommodation entrepreneurship activities (ACCOMMODATION) in Saudi Arabia affect Umrah pilgrims positively ( $p$-value of ACCOMMODATION $=0.006$ which is less than 0.01). While running the bootstrapped quantile regression on small quantiles of 0.2 indicates that accommodation entrepreneurship activities in Saudi Arabia are also positively significant to Umrah pilgrims on a significance level of $10 \%$ (p-value of ACCOMMODATION $=0.090$ which is less than 0.10 ). Those results are consistent with Ekong and Imikan (2016), Karthick and Ganesh (2018), and Song et al. (2020), which indicates the significant contribution of accommodation activities to the development of tourism sector. Besides, the positive effect of entrepreneurship activities of accommodation in Saudi Arabia proved that entrepreneurship is promoting tourism industry and attracts more tourists which is reliable with Ohe (2020), Sheldon and Daniele (2017), Lee-Ross and Lashley, (2008) and Page and Ateljevic (2009).

\section{Conclusion}

For a long time, academics have shown a strong interest in understanding the role of religion in the travel and tourism field, and the link between the Islamic and the tourism industry is increasing in interest and attractiveness, as illustrated by the rising scholarly work published under the term Halal or Islamic tourism in 
recent years. For this reason, this paper is enriching the literature of Islamic tourism by investigating one of the main determinants of the Islamic tourism industry which is accommodation entrepreneurship activities. Besides, this paper filled a literature gap of missing to investigate the link between accommodation entrepreneurship activities and Islamic tourism (Umrah) in Saudi Arabia which is the largest widespread religious tourism in the world. By applying the bootstrapped quantile regression method simultaneously over $0.2,0.5$, and 0.7 , this paper showed that accommodation entrepreneurship activities effect is statistically significant and positive to the Islamic tourism industry (Umrah pilgrimage) in Saudi Arabia all over 0.2, 0.5 and 0.7 quantiles, which confirms that the increase of accommodation entrepreneurship activities in Saudi Arabia is promoting Islamic tourism industry and attracts more Umrah pilgrims (Islamic tourists visitors).

This experimental study has achieved robust evidence that accommodation entrepreneurship activities in Saudi Arabia are a real contribution to Islamic tourism development. As an answer to the main question, accommodation entrepreneurship activities are promoting Islamic tourism industry (Umrah pilgrimage) in Saudi Arabia. According to ALSINI, EKIZ, and HUSSAIN (2019), Wu and Mursid (2019), Islamic life and belief, religious loyalty (Islamic religion loyalty) are the main factors that motivate Umrah and Hajj pilgrims (Islamic tourists) to visit holy places in Saudi Arabia. Therefore, this study confirmed that the accommodation services from the expansion of accommodation entrepreneurship activities in Saudi Arabia are also affecting positively the Umrah pilgrimage development. As a result, the accommodation entrepreneurship activities are one of the main factors like Islamic life and belief, Islamic religion loyalty that attract and bring Umrah pilgrims (Islamic tourists) to Saudi Arabia.

As already stated, Islamic tourism (Halal tourism) is still an underexplored segment, although it is now attracting the interest of tourism experts. Thus, this research is contributing to the literature by demonstrating the importance of accommodation entrepreneurship activities in the Islamic tourism industry which can be an engine to achieve significant economic growth like Saudi Arabia who succeeds to achieve economic growth through the revenues of Umrah and Hajj pilgrimage according to Bokhari (2018).

\section{References:}

[1] Akhy, A. A., and Roy, M. (2020). "Socio-economic Impacts of Accommodation on Tourism Development: Bangladesh Perspective". Tourism Marketing in Bangladesh: An Introduction. Retrieved from https://scholars.cityu.edu.hk/en/publications/socioeconomic-impacts-of-accommodation-on-tourism-development(99f55980-fc6a-4ac1b832-29ccf1a156a2).html

[2] Almuhrzi, H. M., \& Alsawafi, A. M. (2017). "Muslim perspectives on spiritual and religious travel beyond Hajj: Toward understanding motivations for Umrah travel in Oman". Tourism Management Perspectives, 24: $235-242$. https://doi.org/10.1016/j.tmp.2017.07.016

[3] ALSINI, I., EKIZ, E., \& HUSSAIN, K. (2019). “Attributes on Religious Tourist Loyalty in Saudi Arabia”. ISLAMIC TOURISM, 91.

[4] Azevedo, J. P. (2011). “GRQREG: Stata module to graph the coefficients of a quantile regression”. In Statistical Software Components. Boston College Department of Economics. Retrieved from https://ideas.repec.org/c/boc/bocode/s437001.html

[5] Bavik, A., Ekiz, E., \& Xu, B. (2014). "Investigating the Determinants of Destination Satisfaction: Case of International Travelers in Saudi Arabia". The 7th International Conference on Service Management, 10-12.

[6] Bokhari, A. A. H. (2018). "The Economics of Religious Tourism (Hajj and Umrah) in Saudi Arabia”. In Global Perspectives on Religious Tourism and Pilgrimage (pp. 159-184). IGI Global. https://doi.org/10.4018/978-1-5225-2796-1.ch010

[7] Charrel, R. N., Nougairede, A., Brouqui, P., Raoult, D., \& Gautret, P. (2015). "Influenza vaccine for Hajj and Umrah pilgrims". The Lancet Infectious Diseases, 15(3): 267, https://doi.org/10.1016/s1473-3099(15)70035-6

[8] Chin, C.-H., Law, F.-Y., Lo, M.-C., \& Ramayah, T. (2018). “The Impact of Accessibility Quality and Accommodation Quality on Tourists' Satisfaction and Revisit Intention to Rural Tourism Destination in Sarawak: The Moderating Role of Local Communities' Attitude". Global Business and Management Research, 10(2): 115-127.

[9] Cox, N. J. (2005). "Speaking Stata: The Protean Quantile Plot". The Stata Journal: Promoting Communications on Statistics and Stata, 5(3), 442-460. https://doi.org/10.1177/1536867X0500500312

[10] Ebrahim, S. H., \& Memish, Z. A. (2020). “COVID-19: Preparing for superspreader potential among Umrah pilgrims to Saudi Arabia”. Lancet (London, England), 395(10227): e48, https://doi.org/10.1016/s0140-6736(20)30466-9

[11] Ekiz, E., Öter, Z., \& Stephenson, M. L. (2017). “Tourism development in the Kingdom of Saudi Arabia: Determining the problems and resolving the challenges". In International Tourism Development and the Gulf Cooperation Council States (pp. 124-139), https://doi.org/10.4324/9781315776576-8

[12] Ekong, N. C., \& Imikan, A. M. (2016). "Assessing the Impact of Hotels on Socio-Economic Development in Akwa Ibom State: Tourism Perspective". International Journal of Social Sciences, 10(4).

[13] Feng, X., He, X., \& Hu, J. (2011). “Wild bootstrap for quantile regression”. Biometrika, 98(4): 995-999. https://doi.org/10.1093/biomet/asr052 
[14] Hahn, J. (1995). "Bootstrapping Quantile Regression Estimators". Econometric Theory, 11(1): 105-121, https://doi.org/10.1017/s0266466600009051

[15] Hall, C. M., \& Prayag, G. (2020). “The Routledge Handbook of Halal Hospitality and Islamic Tourism”. Routledge.

[16] Hassanli, N., \& Ashwell, J. (2020). "The contribution of small accommodations to a sustainable tourism industry". Current Issues in Tourism, 23(3): 261-264. https://doi.org/10.1080/13683500.2018.1530201

[17] Jamal, A., Raj, R., \& Griffin, K. A. (2019). “Islamic Tourism: Management of Travel Destinations”. CABI.

[18] Jeaheng, Y., Al-Ansi, A., \& Han, H. (2019). "Halal-friendly hotels: Impact of halal-friendly attributes on guest purchase behaviors in the Thailand hotel industry". Journal of Travel \& Tourism Marketing, 36(6): 729-746. https://doi.org/10.1080/10548408.2019.1631940

[19] Jiang, H., Zhang, J., \& Sun, C. (2019). “How does capital buffer affect bank risk-taking? New evidence from China using quantile regression". China Economic Review, 101300, https://doi.org/10.1016/j.chieco.2019.04.008

[20] Karthick, K., \& Ganesh, M. K. (2018). "A Study on the Role of Accommodation for the Promotion of Domestic Tourism in Tamilnadu”. 문화관광연구, 20(2), 46-50.

[21] Koenker, R., \& Bassett, G. (1978). “Regression Quantiles”. Econometrica, 46(1): 33-50, https://doi.org/10.2307/1913643

[22] Lee-Ross, D., \& Lashley, C. (2008). "Entrepreneurship \& Small Business Management in the Hospitality Industry", 15 (Hospitality, Leisure and Tourism).

[23] Machado, J. a. F., Parente, P. M. D. C., \& Silva, J. M. C. S. (2019). “QREG2: Stata module to perform quantile regression with robust and clustered standard errors. Boston College Department of Economics". Retrieved from https://ideas.repec.org/c/boc/bocode/s457369.html

[24] Machado, J. A., \& Silva, J. (2013). "Quantile regression and heteroskedasticity”. Https://Imcss. Som. Surrey. Ac. Uk/IM JSS. Pdf. Accessed, 5(7), 2015.

[25] Mello, M., \& Perrelli, R. (2003). "Growth equations: A quantile regression exploration". The Quarterly Review of Economics and Finance, 43(4): 643-667. https://doi.org/10.1016/S1062-9769(03)00043-7

[26] Nikitina, L., Paidi, R., \& Furuoka, F. (2019). “Using bootstrapped quantile regression analysis for small sample research in applied linguistics: Some methodological considerations". PLOS ONE, 14(1): e0210668. https://doi.org/10.1371/journal.pone.0210668

[27] Ohe, Y. (2020). "Community-based Rural Tourism and Entrepreneurship": A Microeconomic Approach (1st ed. 2020). Springer Singapore.

[28] Othman, B. A., Harun, A. B., \& Nazeer, S. (2018). "Issues and challenges faced by Malaysian umrah travel Agencies in providing excellent marketing mix services to umrah pilgrims". The Journal of Social Sciences Research, 611-618.

[29] Page, S., \& Ateljevic, J. (2009). “Tourism and Entrepreneurship: International Perspectives” (Advances in Tourism Research).

[30] Sahin, M. K., Aker, S., \& Tuncel, E. K. (2015). "Knowledge, attitudes and practices concerning Middle East respiratory syndrome among Umrah and Hajj pilgrims in Samsun, Turkey, 2015". Eurosurveillance, 20(38): 30023. https://doi.org/10.2807/1560-7917.ES.2015.20.38.30023

[31] Sheldon, P. J., and Daniele, R. (2017). Social Entrepreneurship and Tourism: Philosophy and Practice (1st ed.). Springer International Publishing.

[32] Song, H., Xie, K., Park, J., \& Chen, W. (2020). Impact of accommodation sharing on tourist attractions. Annals of Tourism Research, 80, 102820. https://doi.org/10.1016/j.annals.2019.102820

[33] VARGAS-SÁNCHEZ, A., \& MORAL-MORAL, M. (2018). "12 Halal Tourism: Insights from Experts in the Field". Islamic Tourism: Management of Travel Destinations, 154.

[34] Wu, C. H.-J., \& Mursid, A. (2019). "Loyalty motivations for religious tourism: Indonesian Muslim travelers umrah participating in umrah pilgrimage to Mecca, Saudi Arabia". Tourism Review, 75(2), 466-478. https://doi.org/10.1108/TR11-2018-0155 